\title{
Ternesite as a component of sulfobelitic cements
}

\author{
M.T. Blanco-Varela and P.M. Carmona-Quiroga \\ Instituto de Ciencias de la Construcción Eduardo Torroja, Cements and Recycling Materials Department, Madrid, Spain
}

\begin{abstract}
The cement industry is presently devoting substantial effort to the development of less energy intensive, lower emission cements. Calcium sulfoaluminate (CSA) cements, one of the most promising alternatives, are known as 'eco-cements' in light of their lower energy costs and GHG emissions. Whilst their clinker composition may vary, all these cements lie in the $\mathrm{CaO}-\mathrm{A}_{12} \mathrm{O}_{3}-\mathrm{SiO}_{2}-\mathrm{Fe}_{2} \mathrm{O}_{3}-\mathrm{CaSO}_{4}$ system, with constituent minerals that include $\mathrm{C}_{2} \mathrm{~A}, \mathrm{C}_{2} \mathrm{~S}, \mathrm{C}_{12} \mathrm{~A}_{7}, \mathrm{CA}, \mathrm{CS}$, and $\mathrm{C}_{4} \mathrm{AF}$. Ternesite $\left(\mathrm{C}_{5} \mathrm{~S}_{2} \hat{\mathrm{S}}\right)$, a phase compatible with ye'elemite $\left(\mathrm{C}_{4} \mathrm{~A}_{3} \hat{\mathrm{S}}\right)$ and $\mathrm{C}_{2} \mathrm{~S}$, can also be found in that system. Recent studies show that it is activated and hydrated in the presence of $\mathrm{AH}_{3}$ and gypsum, yielding ettringite and C-S-H gel, the main hydration products of CSA and OPC, respectively, as well as $\mathrm{C}_{2} \mathrm{ASH}_{8}$. This study analyses ternesite reactivity in different aluminate blends.
\end{abstract}

\section{Introduction}

The environmental impact of Portland cement manufacture has prompted the industry to implement a number of strategies geared to lowering energy and natural raw material consumption while reducing greenhouse gas, particularly $\mathrm{CO}_{2}$, emissions. The use of secondary cementitious materials (SCMs, often industrial by-products), alternative fuels, grinding additives, along with improvements in combustion, heat exchange and grinding technologies have diminished both consumption and emissions with no detriment to binder properties [1].

Another strategy consists in developing calcium sulfoaluminate cements (CSA) based on ye'elemite $\left(\mathrm{C}_{4} \mathrm{~A}_{3} \hat{\mathrm{S}}\right)$, a phase initially used to produce expansive cement and subsequently stable high-performance binders. CSA cement manufacture is less energyintensive (at $1250{ }^{\circ} \mathrm{C}$, the clinkering temperature is 200 ${ }^{\circ} \mathrm{C}$ lower than in OPC) and, depending on the composition, emits $25 \%$ to $40 \%$ less $\mathrm{CO}_{2}$ than OPC production $[2,3]$. Whilst not presently used for structural purposes for want of the necessary regulation, these cements are commercialised as components in special mortars and concretes (such as repair or self-levelling concrete, sealing mortar or shotcrete).

The composition of the clinker in these cements may differ, although all lie in the $\mathrm{CaO}-\mathrm{A}_{12} \mathrm{O}_{3}-\mathrm{SiO}_{2}-\mathrm{Fe}_{2} \mathrm{O}_{3}$ $\mathrm{CaSO}_{4}$ system and have lower calcium and silicon and higher aluminate and sulfate phase contents than portland cements. The minerals present in the clinker include $\mathrm{C}_{4} \mathrm{~A}_{3} \hat{\mathrm{S}}, \quad \mathrm{C}_{2} \mathrm{~S}, \mathrm{C}_{12} \mathrm{~A}_{7}, \mathrm{CA}, \quad \mathrm{CS}$ and $\mathrm{C}_{4} \mathrm{AF}$, with a predominance of aluminates $[4,5]$.
Ternesite, $\mathrm{C}_{5} \mathrm{~S}_{2} \hat{\mathrm{S}}$, a phase formed in the reaction between anhydrite and beliteand compatible with ye' elemite $\left(\mathrm{C}_{4} \mathrm{~A}_{3} \hat{\mathrm{S}}\right)$ and $\mathrm{C}_{2} \mathrm{~S}$, also lies within this system.

Ternesite was found as a natural mineral at Ettringer Bellerberg, near Mayen, Eifel, Germany, in the nineteen nineties. Its synthetic form had been identified earlier, however, as a component of cement [6] or lime [7] kiln crust, the sulphur for which was sourced from the fuel, as well as a minority component in some CSA cements $[8,9,10]$.

Ternesite was chemically, physically, structurally and petrologically characterised between 1960 and 2000 $[6,7,11-13]$. Regarded as a non-hydraulic material [1415] until it was recently proven to be activated by aluminium hydroxide [16], it has since become a target for research. This paper describes some of the characteristics of ternesite and its hydraulic activation by other mineral compounds.

\section{Physical and structural characteristics}

Natural [11] and synthetic ternesite, which are identical, are isostructural with silicocarnotite, $\mathrm{Ca}_{5}\left(\mathrm{PO}_{4}\right)_{2} \mathrm{SiO}_{4}[12,13]$.The unit-cell parameters of this orthorhombic mineral,Pnma space group crystal are $\mathrm{a}=$ 6.863(1) $\AA, b=15.387(2) \AA, c=10.181(1) \AA, Z=4$.Its structure consists in isolated $\mathrm{SiO}_{4}$ and $\mathrm{SO}_{4}$ tetrahedral units connected by octa- or heptahedrally coordinated $\mathrm{Ca}$ ions. Both S and Si tetrahedrally coordinated with oxygen occupy different tetrahedral positions in the structure, in which double layers of silicate tetrahedral alternate with a layer of sulphate tetrahedral. Natural ternesite is optically biaxial and negative, with refractive index $\mathrm{n}_{\mathrm{x}}=1.630, \mathrm{n}_{\mathrm{y}}$ $=1.637$ and $\mathrm{n}_{\mathrm{z}}=1.640$ and an optical angle, $2 \mathrm{~V}_{\mathrm{x}}=63.5^{\circ}$. 


\section{Thermal stability of ternesite}

$\mathrm{C}_{5} \mathrm{~S}_{2} \hat{\mathrm{S}}$ thermal stability has been studied by several authors, some of whom position it in a narrow range of temperatures $\left(1100{ }^{\circ} \mathrm{C}\right.$ to $1180^{\circ} \mathrm{C}[16]$ or $1200^{\circ} \mathrm{C}$ to 1298 ${ }^{\circ} \mathrm{C}[15]$ ), above which it would decompose further to the equation:

$\mathrm{Ca}_{5}\left(\mathrm{SiO}_{4}\right)_{2} \mathrm{SO}_{4} \rightleftharpoons 2 \mathrm{Ca}_{2} \mathrm{SiO}_{4}+\mathrm{CaSO}_{4}$.

The decomposition temperature depends on whether it is determined in an open $\left(\approx 1180{ }^{\circ} \mathrm{C}\right)$ or closed $\left(1289^{\circ} \mathrm{C}\right)$ system at a total pressure of $1 \mathrm{~atm}$. [17,18].Similar findings $\left(\approx 12900^{\circ} \mathrm{C}\right.$ at $1 \mathrm{~atm}$.) were reported by Hanein et al. [19], who determined the thermodynamic constants of ternesite to lie between $1000{ }^{\circ} \mathrm{C}$ and $1400^{\circ} \mathrm{C}$, based on previously published vapour pressure measurements of several sulphates obtained between those temperatures [22]. Those studies showed that the vapour pressure of ternesite, like that of anhydrite, rises with temperature, while ternesite exhibits a pressure lower than anhydrite at 1000 to $1290{ }^{\circ} \mathrm{C}$ and higher above that range.
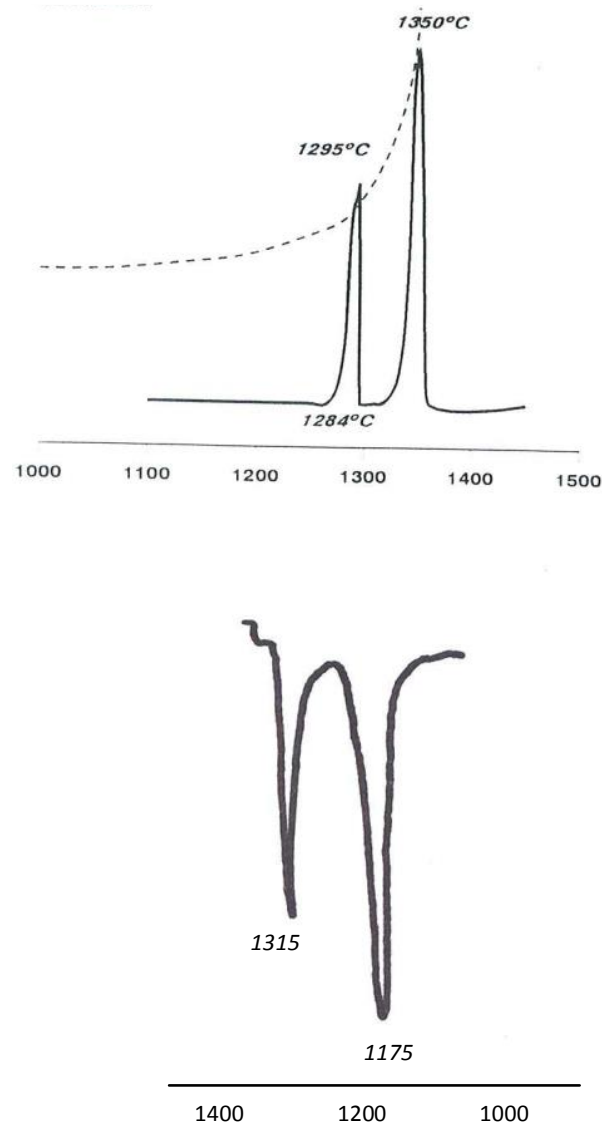

Fig. 1.DTA/TG curves for ternesite, heating (top) and cooling (bottom)

The decomposition reaction of ternesite would also depend, then, on the rate of $\mathrm{SO}_{2}$ loss and for high temperatures could be described by the equation:

$\mathrm{Ca}_{5}\left(\mathrm{SiO}_{4}\right)_{2} \mathrm{SO}_{4} \rightleftharpoons 2 \mathrm{Ca}_{2} \mathrm{SiO}_{4}+\mathrm{CaO}+\mathrm{SO}_{2}+1 / 2 \mathrm{O}_{2}$, in which ternesite thermal decomposition would be a function of temperature and the partial pressure of $\mathrm{SO}_{2}$ and $\mathrm{O}_{2}$.

For a given temperature and partial pressure of $\mathrm{O}_{2}$ (which must always be higher than in $\mathrm{SO}_{2}$ for $\mathrm{SO}_{3}$ to form), there is a maximum $\mathrm{SO}_{2}$ pressure above which ternesite does not form [19].

On the DTA curve $\left(10{ }^{\circ} \mathrm{C} / \mathrm{min}\right.$ in $\mathrm{CO}_{2}$-free air), ternesite thermal decomposition induces an endothermal peak at around $1290{ }^{\circ} \mathrm{C}$. As the temperature rises, a second endothermal peak appears due to the fusion of the $\mathrm{C}_{2} \mathrm{~S}_{-}-\mathrm{CaSO}_{4}$ eutectic, which accounts for $10 \%-20 \%$ of the composition of $\mathrm{CaSO}_{4}$ [18].Mass loss intensifies on the TG curve at temperatures of over $1200{ }^{\circ} \mathrm{C}$. During cooling, the DTA curve exhibits two exothermal peaks, respectively denoting the solidification of the $\mathrm{C}_{2} \mathrm{~S}_{-} \mathrm{CaSO}_{4}$ eutectic $\left(1310{ }^{\circ} \mathrm{C}\right)$ and the $\alpha$ to $\beta$ polymorphic transformation of $\mathrm{CaSO}_{4}\left(1175^{\circ} \mathrm{C}\right)$. No signal whatsoever is detected that would indicate new ternesite formation along cooling. FTIR and XRD identify $\alpha^{\prime} \mathrm{C}_{2} \mathrm{~S}$ and anhydrite (traces of $\mathrm{CaO}$ on the XRD pattern), but no ternesite, an indication that at the cooling rate applied (10 ${ }^{\circ} \mathrm{C} / \mathrm{min}$ ) the decomposition reaction is not reversible.

Table 1.Minerals forming after ternesite thermal treatment

\begin{tabular}{|c|c|c|}
\hline $\mathrm{T}\left({ }^{\circ} \mathrm{C}\right)$ & Time & Phases \\
\hline 1315 & $20 \mathrm{~min}$ & $\begin{array}{c}\alpha_{\mathrm{L}}^{\prime} \mathrm{C}_{2} \mathrm{~S} ; \mathrm{CaSO}_{4} ; \\
\mathrm{CaO}\end{array}$ \\
\hline 1400 & $20 \mathrm{~min}$ & $\begin{array}{c}\alpha_{\mathrm{L}}^{\prime} \mathrm{C}_{2} \mathrm{~S} ; \mathrm{CaSO}_{4} ; \\
\mathrm{CaO}\end{array}$ \\
\hline $\begin{array}{c}1315 \text { and } \\
1000\end{array}$ & $\begin{array}{c}20 \text { min and } \\
24 \mathrm{~h}\end{array}$ & $\begin{array}{c}\alpha_{\mathrm{L}}^{\prime} \mathrm{C}_{2} \mathrm{~S} ; \\
\mathrm{Ca}_{5} \mathrm{~S} \mathrm{~S}_{2} \mathrm{~S} ; \mathrm{CaO}\end{array}$ \\
\hline $\begin{array}{c}1400 \text { and } \\
1000\end{array}$ & $\begin{array}{c}20 \text { min and } \\
24 \mathrm{~h}\end{array}$ & $\begin{array}{c}\alpha_{\mathrm{L}}^{\prime} \mathrm{C}_{2} \mathrm{~S} ; \mathrm{CaSO}_{4} \\
\mathrm{CaO}\end{array}$ \\
\hline
\end{tabular}

The XRD findings for ternesite exposed to different thermal treatments (Table 1) suggest that once it decomposes, its recrystallization depends on the cooling rate and the temperature reached. Recrystallization is possible after reheating to $1000{ }^{\circ} \mathrm{C}$ when the temperature reached does not exceed the melting point of the eutectic; otherwise, recrystallization does not appear to occur.

According to the literature, ye'elemite, ternesite and anhydrite clinkers at a ratio (by weight) of 1:1:0.5 can be obtained from traditional raw materials or industrial byproducts at temperatures of around $1200{ }^{\circ} \mathrm{C}$ [14].Twostage clinkerización has also been successfully applied to produce such cements, clinkering the raw meal at 1250 ${ }^{\circ} \mathrm{C}$ for $1 \mathrm{~h}$, followed by gradual cooling to $1100{ }^{\circ} \mathrm{C}$ and quick cooling below that temperature [10,20,21].Singlestage belite and ternesite-rich calcium sulphoaluminate $(\mathrm{BY}(\mathrm{F}) \mathrm{T})$ have been obtained at a maximum temperature of $1260{ }^{\circ} \mathrm{C}$ in a pilot plant where the partial pressure of $\mathrm{O}_{2}$ and $\mathrm{SO}_{2}$ was controlled in the kiln [19].

\section{Compatibility between ternesite and $\mathrm{CaO}-\mathrm{SiO}_{2}-\mathrm{A}_{12} \mathrm{O}_{3}-\mathrm{CaSO}_{4}$ system phases}

The following is a discussion of some of the features of the equilibrium phases of the three subsystems most 
closely related to the chemistry of cement, namely: $\mathrm{CaO}-$ $\mathrm{SiO}_{2}-\mathrm{A}_{12} \mathrm{O}_{3} ; \mathrm{CaO}-\mathrm{SiO}_{2}-\mathrm{CaSO}_{4}$ and $\mathrm{CaO}-\mathrm{A}_{12} \mathrm{O}_{3}-\mathrm{CaSO}_{4}$.

The equilibrium phases of the system $\mathrm{CaO}-\mathrm{SiO}_{2}-$ $\mathrm{A}_{12} \mathrm{O}_{3}$ have long been known in the fields of cement chemistry and ceramics [23]. In addition to mullite, the calcium silicates $\left(\mathrm{C}_{3} \mathrm{~S}, \mathrm{C}_{2} \mathrm{~S}, \mathrm{C}_{3} \mathrm{~S}_{2}, \mathrm{CS}\right)$ and calcium aluminates $\left(\mathrm{C}_{3} \mathrm{~A}, \mathrm{C}_{12} \mathrm{~A}_{7}, \mathrm{CA}, \mathrm{CA}_{2}, \mathrm{CA}_{6}\right)$, the system includes two ternary phases: gehlenite and akermanite. $\mathrm{C}_{2} \mathrm{~S}$ is compatible with $\mathrm{C}_{3} \mathrm{~A}, \mathrm{C}_{12} \mathrm{~A}_{7}, \mathrm{CA}$ and gehlenite, as well as with $\mathrm{C}_{3} \mathrm{~S}$ and $\mathrm{C}_{3} \mathrm{~S}_{2}$.

In system $\mathrm{CaO}-\mathrm{SiO}_{2}-\mathrm{CaSO}_{4}, \mathrm{CaSO}_{4}$ is incompatible at $1100{ }^{\circ} \mathrm{C}$ with $\mathrm{C}_{2} \mathrm{~S}$, with which it reacts to form ternesite. Consequently, the equilibrium phases in the $\mathrm{CaO}$-rich zone would be: i) $\mathrm{CaO}-\mathrm{CaSO}_{4}-\mathrm{Ca}_{5} \mathrm{~S}_{2} \hat{\mathrm{S}}$; ii) $\mathrm{CaO}-\mathrm{C}_{2} \mathrm{~S}-$ $\mathrm{Ca}_{5} \mathrm{~S}_{2} \hat{\mathrm{S}}$; iii) $\mathrm{C}_{2} \mathrm{~S}-\mathrm{Ca}_{5} \mathrm{~S}_{2} \hat{\mathrm{S}}-\mathrm{C}_{3} \mathrm{~S}_{2}$; iv) $\mathrm{CaSO}_{4}-\mathrm{Ca}_{5} \mathrm{~S}_{2} \hat{\mathrm{S}}-\mathrm{C}_{3} \mathrm{~S}_{2}$ [18].

A ternary phase, $\mathrm{C}_{4} \mathrm{~A}_{3} \hat{\mathrm{S}}$, present in system $\mathrm{CaO}$ $\mathrm{A}_{12} \mathrm{O}_{3}-\mathrm{CaSO}_{4}$, is positioned in between the $\mathrm{CaSO}_{4}$ and the $\mathrm{C}_{3} \mathrm{~A}, \mathrm{C}_{12} \mathrm{~A}_{7}$ and $\mathrm{CA}$. The phases in the Ca-rich zone of the system that are compatible at temperatures under $1350{ }^{\circ} \mathrm{C}$ are: i) $\mathrm{CaO}-\mathrm{CS}-\mathrm{C}_{4} \mathrm{~A}_{3} \hat{\mathrm{S}}$; ii) $\mathrm{CaO}-\mathrm{C}_{3} \mathrm{~A}-\mathrm{C}_{4} \mathrm{~A}_{3} \hat{\mathrm{S}}$; iii) $\mathrm{C}_{3} \mathrm{~A}-\mathrm{C}_{12} \mathrm{~A}_{7}-\mathrm{C}_{4} \mathrm{~A}_{3} \hat{\mathrm{S}}$; iv) $\mathrm{C}_{12} \mathrm{~A}_{7}-\mathrm{CA}-\mathrm{C}_{4} \mathrm{~A}_{3} \hat{\mathrm{S}}$ [24].

Studying system $\mathrm{CaO}-\mathrm{SiO}_{2}-\mathrm{A}_{12} \mathrm{O}_{3}-\mathrm{CaSO}_{4}$ at temperatures between $950{ }^{\circ} \mathrm{C}$ and $1150{ }^{\circ} \mathrm{C}$, Pliego-Cuervo [9] found ternesite to be incompatible with $\mathrm{C}_{12} \mathrm{~A}_{7}$ and $\mathrm{CA}$, and both $\mathrm{C}_{2} \mathrm{~S}$ and $\mathrm{C}_{3} \mathrm{~A}$ to be compatible with ternesite, ye'elemite or both. The compatible phases in the $\mathrm{CaO}-$ rich zones of the system were identified as: i) i) $\mathrm{CaO}-\mathrm{CS}$ $\mathrm{C}_{4} \mathrm{~A}_{3} \hat{\mathrm{S}}-\mathrm{C}_{5} \mathrm{~S}_{2} \hat{\mathrm{S}}$; ii) $\mathrm{CaO}-\mathrm{C}_{3} \mathrm{~A}-\mathrm{C}_{4} \mathrm{~A}_{3} \hat{\mathrm{S}}-\mathrm{C}_{5} \mathrm{~S}_{2} \hat{\mathrm{S}}$; iii) $\mathrm{CaO}-\mathrm{C}_{2} \mathrm{~S}-$ $\mathrm{C}_{3} \mathrm{~A}-\mathrm{C}_{5} \mathrm{~S}_{2} \hat{\mathrm{S}}$; iv) $\mathrm{C}_{3} \mathrm{~A}-\mathrm{C}_{2} \mathrm{~S}-\mathrm{C}_{5} \mathrm{~S}_{2} \hat{\mathrm{S}}-\mathrm{C}_{4} \mathrm{~A}_{3} \hat{\mathrm{S}}$; v) $\mathrm{C}_{2} \mathrm{~S}-\mathrm{C}_{12} \mathrm{~A}_{7-}$ $\mathrm{C}_{3} \mathrm{~A}-\mathrm{C}_{4} \mathrm{~A}_{3} \hat{\mathrm{S}}$; vi) $\mathrm{C}_{2} \mathrm{~S}-\mathrm{C}_{12} \mathrm{~A}_{7}-\mathrm{CA}-\mathrm{C}_{4} \mathrm{~A}_{3} \hat{\mathrm{S}}$.

Strigac [23] broadened the field of study, identifying two new sets of compatible phases in which ye'elemite and ternesite would co-exist: vii) $\mathrm{C}_{2} \mathrm{~S}_{-}-\mathrm{C}_{3} \mathrm{~S}_{2}-\mathrm{C}_{4} \mathrm{~A}_{3} \hat{\mathrm{S}}-\mathrm{C}_{5} \mathrm{~S}_{2} \hat{\mathrm{S}}$; viii) $\mathrm{C}_{2} \mathrm{AS}-\mathrm{C}_{3} \mathrm{~S}_{2}-\mathrm{C}_{4} \mathrm{~A}_{3} \hat{\mathrm{S}}-\mathrm{C}_{5} \mathrm{~S}_{2} \hat{\mathrm{S}}$.

Ye'elemite and ternesite can co-exist, then, not only in calcium-rich zones of the system but also in areas with less $\mathrm{CaO}$ and more $\mathrm{CaSO}_{4}$ and $\mathrm{SiO}_{2}$, although obviously at temperatures below the ternesite decomposition threshold.

\section{Ternesite activation}

Although a number of authors have concluded that ternesite is a non-hydraulic phase [14-15], as early as 1992Berteka et al. [25] synthesised clinkers consisting primarily in ye'elemite and ternesite, with anhydrite as a residual phase. Produced at $1200^{\circ} \mathrm{C}$, they exhibited very high strength after hydration. Later studies [16] showed that ternesite hydration would be moderate and very slow.

According to Ben Haha et al. [26], ternesite can be activated with aluminate hydroxide to yield ettringite, stratlingite and $\mathrm{C}-\mathrm{S}-\mathrm{H}$, the proportions of which depend on the proportion among reactives and their degree of reaction. Bullerjahn et al. [27] reported that ternesite contributed more to early age cement properties than $\mathrm{C}_{2} \mathrm{~S}$ in the CSA cements they synthesised.

Montes et al. [28] showed that ternesite can also be activated by other aluminates, such as $\mathrm{C}_{3} \mathrm{~A}, \mathrm{C}_{12} \mathrm{~A}_{7}, \mathrm{CA}$ and $\mathrm{C}_{4} \mathrm{~A}_{3} \hat{\mathrm{S}}$, and established the order of activating effectiveness as: $\mathrm{C}_{12} \mathrm{~A}_{7}>\mathrm{CA}>\mathrm{C}_{3} \mathrm{~A} \gg>>>\mathrm{C}_{4} \mathrm{~A}_{3} \hat{\mathrm{S}}$.

The calorimetric curves for hydrated aluminate pastes contain a first dissolution peak, followed by an induction period and an intense reaction peak in pastes $\mathrm{CA}, \mathrm{C}_{12} \mathrm{~A}_{7}$ and $\mathrm{C}_{4} \mathrm{~A}_{3} \hat{\mathrm{S}}$ [29-31]. In 2:1 ternesite: aluminate blends hydrated at $25{ }^{\circ} \mathrm{C}$ for $7 \mathrm{~d}$, the presence of ternesite in the pastes was reported to alter the calorimetric curves of four aluminates, shortening the induction period and bringing the reaction peak forward [28].

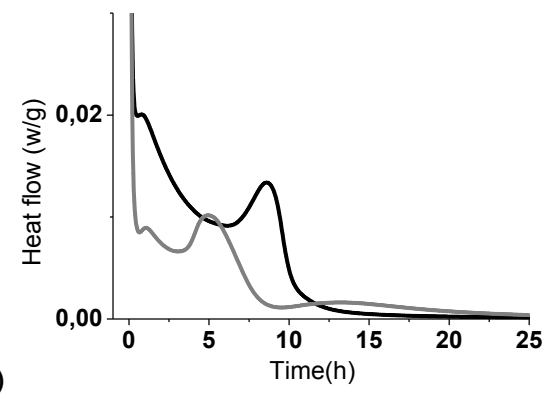

a)

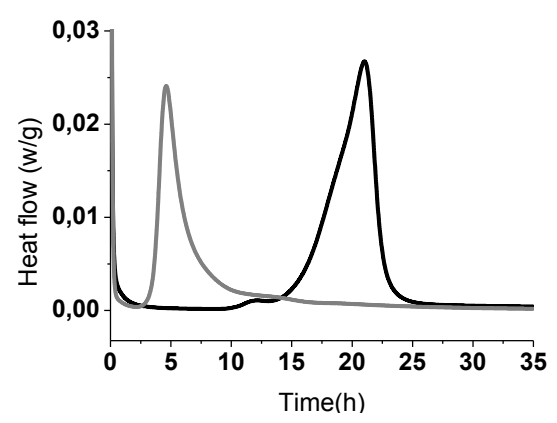

b)

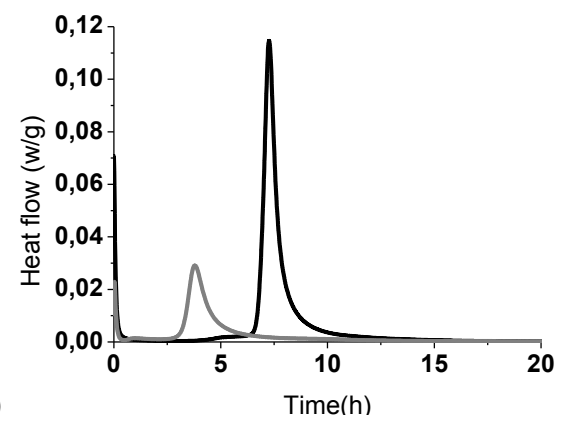

Figure 2.Heat flow curves for: a) $\mathrm{C}_{12} \mathrm{~A}_{7}$ (black), $\mathrm{C}_{12} \mathrm{~A}_{7}+$ ternesite (grey); b) CA (black), CA+ternesite (grey); c) $\mathrm{C}_{4} \mathrm{~A}_{3} \hat{\mathrm{S}}$ (black), $\mathrm{C}_{4} \mathrm{~A}_{3} \hat{\mathrm{S}}+$ ternesite (grey)

The presence of ternesite alters the hydration products of the aluminates. Pastes obtained after calorimetric studies of the ternesite/aluminate blends contain $\mathrm{C}_{4} \mathrm{AS}_{\mathrm{S}} \mathrm{H}_{12}$ as a hydration product. $\mathrm{C}_{2} \mathrm{ASH}_{8}$ is also found in pastes containing $\mathrm{C}_{12} \mathrm{~A}_{7}$ or $\mathrm{CA}$. Stratlingite forms neither in ternesite $+\mathrm{C}_{3} \mathrm{~A}$ pastes nor in the pastes with $\mathrm{C}_{4} \mathrm{~A}_{3} \hat{\mathrm{S}}$, in which amorphous $\mathrm{AH}_{3}$ is present [29].

Acknowledgements. This paper was funded under research project BIA2016-76466-R and by the Regional Government of Madrid and the European Social Fund (Geomaterials Programme2 S2013/MIT-2914). 


\section{References}

1. J.S. Damtoft, J. Lukasik, D. Herfort, D. Sorrentino, E.M. Gartner, "Sustainable development and climate change initiatives",Cem. Concr. Res. 38 (2) 115-127 (2008)

2. E.M. Gartner," Industrially interesting approaches to "low- $\mathrm{CO}_{2}$ " cements",Cem. Concr. Res. 34, 14891498, (2004).

3. M.C.G. Juenger, F. Winnefeld, J.L. Provis, J.H. Ideker, "Advances in alternative cementitious binders", Cem. Concr. Res. 41, 1232-1243, (2011).

4. M. Carmen Martín-Sedeño, A.J.M. Cuberos, A. G. De la Torre, G.Álvarez-Pinazo, L. M. Ordónez; MilenGateshkic, M.A.G. Aranda. "Aluminum-rich belitesulfoaluminate cements: Clinkering and early age hydration".Cem.Concr. Res. Volume 40, (3), March 359-369, (2010).

5. K. Morsli, A.G. de la Torre, M. Zahir, M.A.G. Aranda. "Mineralogical phase analysis of alkali and sulfate bearing belite rich laboratory clinkers".Cem.Concr. Res., 37 639-646, (2007)

6. N.Sundius, Peterson (1960) "Doppelvereinigung von Sulfat und SilikataussogenanntenSulfatringen in den Zementtfen in Limnham".Radex-Rundschau. 100103 (1960).

7. M.W. Pryce "Calcium sulphosilicate in lime-kiln wall coating”. Min Mag 38:968-971, (1972)

8. M.Marroccoli, F.Montagnaro,M.L. Pace, A. Telesca, G.L. Valenti, "Synthesis of calcium sulfoaluminate cements from blends of coal combustion ashes with flue gas desulfurization gypsum", PTSE, Ischia, Italy, 2010.

9. Y.B. Pliego-Cuervo, F.P. Glasser, "The role of sulphates in cement clinkering: subsolidus phase relations in the system $\mathrm{CaO}-\mathrm{A}_{12} \mathrm{O}_{3}-\mathrm{SiO}_{2}-$ $\mathrm{SO}_{3}$ ".Cem.Concr. Res., 9, 51-56, (1979).

10. F.Bullerjahn, D.Schmitt, \&M.BenHaha, "Effect of raw mix design and of clinkering process on the formation and mineralogical composition of (ternesite) belite calcium sulphoaluminate ferrite clinker".Cem.Concr. Res., 59, 87-95, (2014).

11. E. Irran, E. Tillmanns, and G. Hentschel."Ternesite, $\mathrm{Ca}_{5}\left(\mathrm{SiO}_{4}\right)_{2} \mathrm{SO}_{4}$, a new mineral from the EttringerBellerberg/Eifel, Germany" Mineralogy and Petrology 60:121-132, (1997).

12. B. Dickens, WE. Brown "The crystal structure of $\mathrm{Cas}\left(\mathrm{PO}_{4}\right) 2 \mathrm{SiO}_{4}$ (silico-carrlotite)".Tschermaks Min Petr Mitt 16:1-27, (1971).

13. PD. Brotherton ,JM Epstein , MW.Pryce,AH.White "Crystal structure of 'calcium sulphosilicate', $\mathrm{Ca}_{5}\left(\mathrm{SiO}_{4}\right)_{2} \mathrm{SO}_{4}$ ". Aust J Chem 27:657-660, (1974).

14. N. Sherman, J. Beretka, L.Santoro and G.L. Valenti"Long-term behaviour of hydraulic binders based on calcium sulfoaluminate and calcium sulfosilicate"Cem. Concr.Res, Vol. 25. No. 1, pp. 113-126,1995

15. Su, Muzhen, W.Kurdowski, F. Sorrentino, Developpement in non Portland cements". IX. ICCC, Vol.1, p.317, New Delhi (1992).

16. Sahu, "Developpements in Low energy cements". Ceramics-Silikáty.38 191-, (1994)
17. W. Gutt, M.A. Smith, "A new calcium silicosulphate," Nature 210, 408-409, (1966).

18. W. Gutt, M.A. Smith, "Studies of sub-system CaOCaO. $\mathrm{SiO}_{2}-\mathrm{CaSO}_{4}$, Trans Br."Ceram.Soc. 66 557567, (1967).

19. T. Hanein, I. Galan, F. P. Glasser, S.Skalamprinos, A. Elhoweris, M.S. Imbabi, M.N. Bannerman, "Stability of ternesite and the production at scale of ternesite-based clinkers,"Cem. Concr. Res. 98, 91100 (2017)

20. F. Bullerjahn, D. Schmitt, M. B. Haha, "Method for producing ternesite," US9073785 B2 (2015).

21. W. Dienemann, D. Schmitt, F. Bullerjahn, "Belitecalciumsulfoaluminate-ternesite (BCT)-a new low carbon clinker technology,"Cem. Int. 11, 100-109, (2013).

22. Gang-Soon Choi and F.P. Glasser"The sulphur cycle in cement kilns: vapour pressures and solid-phase stability of the sulphate phases"Cem. Concr. Res. 18, .367-374, (1988)

23. J. Strigac, S. Sahu, M. Lopasovska, R. Durovcikova, V. Kovar, J. Majling, Phase Compatibility in the system $\mathrm{CaO}-\mathrm{SiO}_{2}-\mathrm{A}_{12} \mathrm{O}_{3}-\mathrm{SO}_{3}$," Ceramics 42 90-98, (1998).

24. I.Kaprálik , F.Hanic,"Phase changes in the system $\mathrm{CaO}-\mathrm{SiO}_{2}-\mathrm{A}_{12} \mathrm{O}_{3}-\mathrm{Fe}_{2} \mathrm{O}_{3} \mathrm{MgO}-\mathrm{CaSO}_{4}-\mathrm{K}_{2} \mathrm{SO}_{4}$ in air up to $1300^{\circ} \mathrm{C}$ referred to sulphoaluminate cement clinker”Br.Ceram.Trans.J. 85, 131 (1986)

25. J.Beretka, L.Santoro, N.Sherman, G.L.Valenti, "Synthesis and properties of low energy cements base don $\mathrm{C}_{4} \mathrm{~A}_{3}$ s". XI. ICCC, Vol.3, p.195, New Delhi 1992

26. M. B. Haha, F.Bullerjahn, MaciejZajac"On the reactivity of ternesite" 14th ICCC, Pekín 2015

27. Frank Bullerjahn • MaciejZajac •M.B. Haha "CSA raw mix design: effect on clinker formation and reactivity" Materials and Structures 48:3895-3911, (2015)

28. M. Montes; M.T.Blanco Varela "Can calcium aluminates activate ternesite hydration?"Cem. Concr.Res. 103, 204-2015 (2018).

29. B. Raab, H. Poellmann, "Heat flow calorimetry and SEM investigations to characterize the hydration at different temperatures of different $12 \mathrm{CaO} \cdot \mathrm{A}_{12} \mathrm{O}_{3}$ $\left(\mathrm{C}_{12} \mathrm{~A}_{7}\right)$ samples synthesized by solid state reaction, polymer precursor process and glycine nitrate process Thermochimica"Acta 513, 106-111, (2011).

30. M.J. Sánchez-Herrero, A. Fernández-Jiménez, A.Palomo, " $\mathrm{C}_{4} \mathrm{~A}_{3} \hat{\mathrm{S}}$ hydration in different alkaline media,”Cem.Concr.Res. 46, 41-49, (2013).

31. S.R. Klaus, J. Neubauer, F. Goetz-Neunhoeffer, "Hydration kinetics of $\mathrm{CA}_{2}$ and CAInvestigations performed on a synthetic calcium aluminate cement,"Cem.Concr.Res. 43 62-69, (2013). 